\title{
Antioxidant Potential of Parsley Leaf (Petroselinum crispum) Essential Oil on Hypothyroidism and Testicular Injury in Mice Intoxicated by Carbon Tetrachloride
}

\author{
Gehan M. Badr $\mathbb{D},{ }^{1}$ Abdulmohsen I. Algefare, ${ }^{2}$ and Manal A. Alfwuaires $\mathbb{D}^{2}$ \\ ${ }^{1}$ Department of Zoology, Faculty of Science, Ain Shams University, Cairo, 11566, Egypt \\ ${ }^{2}$ Department of Biological Sciences, Faculty of Science, King Faisal University, P.O. Box 380, Al-Ahsa 31982, Saudi Arabia \\ Correspondence should be addressed to Gehan M. Badr; gehanbadr1972_8@yahoo.com
}

Received 3 March 2021; Revised 10 July 2021; Accepted 13 August 2021; Published 30 August 2021

Academic Editor: Maqusood Ahamed

Copyright (C) 2021 Gehan M. Badr et al. This is an open access article distributed under the Creative Commons Attribution License, which permits unrestricted use, distribution, and reproduction in any medium, provided the original work is properly cited.

\begin{abstract}
The aim of the present study was to investigate the ameliorative potential of parsley (Petroselinum crispum) leaf essential oil (PO) against the detrimental effects of carbon tetrachloride $\left(\mathrm{CCl}_{4}\right)$ on the thyroid gland and testes of mice. Twenty-four adult male mice were divided into four groups and treated for 4 weeks. The $1^{\text {st }}$ control group received $3 \mathrm{~mL} / \mathrm{kg}$ olive oil intraperitoneally, twice a week followed by $0.5 \mathrm{~mL} / \mathrm{kg}$ saline intragastrically daily. The $2^{\text {nd }} \mathrm{CCl}_{4}$ group received $\mathrm{CCl}_{4}(3 \mathrm{~mL} / \mathrm{kg}$ intraperitoneally, twice a week). The $3^{\text {rd }} \mathrm{PO}$ group received $\mathrm{PO}\left(0.5 \mathrm{~mL} / \mathrm{kg}\right.$ intragastrically daily), while the $4^{\text {th }} \mathrm{CCl}_{4}+\mathrm{PO}$ group received $\mathrm{CCl}_{4}$ coadministrated with $\mathrm{PO}$ at the aforementioned doses. $\mathrm{CCl}_{4}$ group recorded significant $(p<0.05)$ reduction in the activities of antioxidant enzyme catalase (CAT) and superoxide dismutase (SOD) and significant $(p<0.05)$ increase in the lipid peroxidation end product's level malondialdehyde (MDA) in the testes and thyroid glands. Meanwhile, serum levels of testosterone, follicle-stimulating hormone (FSH), luteinizing hormone (LH), and thyroid hormones (thyroid-stimulating hormone (TSH), total triiodothyronine (T3), free triiodothyronine (fT3), total thyroxine (T4), and free thyroxine (fT4)) significantly decreased. Also, histopathologically, the testicular tissue showed hypospermatogenesis within irregular-shaped seminiferous tubules with prominent edema in the interstitial spaces confirming the aforementioned biochemical alterations. Treatment with PO significantly reduced the testicular and thyroid oxidative stress $(p<0.05)$ and elevated the testosterone (73.47\%), FSH (92.11\%), LH (33.33\%), T3 (23.47\%), fT3 (39.13\%), T4 (27.91\%), and fT4 (75\%) as compared to that of CCl ${ }_{4}^{-}$ treated group corresponding values. The PO GC/MS analysis indicated bioactive monoterpenes (major component is 1,3,8mentha triene $34.48 \%$ ) and phenylpropenes (major component is myristicin $21.04 \%$ ). Results suggested the ameliorative effect of $\mathrm{PO}$ against $\mathrm{CCl}_{4}$-induced hypogonadism in mice by suppressing oxidative stress and maintaining thyroid gland function.
\end{abstract}

\section{Introduction}

Oxidative stress defined as disturbance in the balance between the production of free radicals and the antioxidants (enzymatic and nonenzymatic) of the body which protect their adverse alterations in lipids, proteins, and DNA and trigger diseases. That is like its great significance for the maintenance of reproductive potential and endocrine stability in testes and ovaries $[1,2]$. From the oxygen-containing free radicals occurring in many disease states are hydroxyl radical, superoxide anion radical, hydrogen peroxide, oxygen singlet, hypochlorite, nitric oxide radical, and peroxynitrite radical. The source of these reactive oxygen species (ROS) derived normally through the metabolic processes or after exposure to environmental pollutants, smoking, addiction, radiation, and infections $[3,4]$.

Increased testicular oxidative stress leads to germ cell apoptosis and subsequently hypospermatogenesis, where 
oxidative stress offered testicular changes in the dynamics of the microvascular blood flow, endocrine signaling, and germ cell apoptosis and reported as a trigger in male infertility [5]. Oxidative stress in testicular tissue decreased antioxidant enzymes and increased the production of $\mathrm{NO}, \mathrm{H}_{2} \mathrm{O}_{2}$, and lipid peroxidation. Also, it increased apoptosis rate, induced DNA damage in sperm cells, and drained the seminal plasma antioxidants [6-8].

In addition, hypothyroidism is a state of increased oxidative stress [9], where the thyroid hormones regulate the metabolism of hepatocytes while the liver metabolizes thyroid hormones indicating the close connection between the liver and thyroid hormones, and dysfunction of one causes a disturbance in the other [10]. It was confirmed that hyperthyroidism markedly causes alterations of the gonadotropic and prolactin axis and dramatically affects spermatic function [11]. Hyperthyroidism is associated with oxidative stress in testicles, with increased lipid peroxidation and decreased GSH level, in addition to increased mitochondrial activity and concurrent release of electrons from mitochondrial electron transport chain due to increased production of thyroxine [12].

Carbon tetrachloride $\left(\mathrm{CCl}_{4}\right)$ compound is used as hepatotoxic and nephrotoxic in animal models and is prooxidant which induces oxidative stress resulting in damage to body tissues by generation of free radicals, trichloromethyl $(\bullet \mathrm{CCl} 3)$ and trichloromethylperoxy $(\bullet \mathrm{CCl} 3 \mathrm{O} 2)$, and other metabolites produced by cytochrome $\mathrm{P} 450$. They initiate lipid peroxidation by attacking polyunsaturated fatty acids in membranes, responsible for cellular damage by alteration of cellular structure, and develop through multiple organ dysfunction by these free radicals [13-18]. Oxidative stress induced by carbon tetrachloride in rats increases the level of TBARS and nitrites along with decrease in reduced glutathione and various antioxidant enzymes in testis accompanied by partial degeneration of germ and Leydig cells along with deformities in spermatogenesis [19].

Parsley (Petroselinum crispum; family Apiaceae) is a natural food additive and a valuable medicinal plant that is regularly consumed by humans. Parsley leaf oil, an essential oil, has a flavor that resembles that of the fresh herb. It is known to exhibit antioxidant, anti-inflammatory, and antiapoptotic effects in several tissues [20]. The major components of the essential oil extracted from parsley leaves are $\alpha$-pinene, myristicin, and apiole [21]. In addition, Simon and Quinn reported that 1,3,8-p-menthatriene, $\beta$-phellandrene, myristicin, apiol, and myrcene are found in this essential oil [22]. Myristicin is a major volatile aroma constituent of parsley oil with cancer chemopreventive, antiinflammatory, and free radical scavenging effects $[23,24]$. Moreover, the two isomers $\alpha$ - and $\beta$-pinene are well-known monoterpenes present in parsley, and many plant essential oils have antitumor, antioxidant, and anti-inflammatory effect [25]. Also, limonene protected the cells to the oxidative stress induced by exogenous $\mathrm{H}_{2} \mathrm{O}_{2}$ [26]. The aim of the current study was to investigate the potential protective effect of essential leaf oil of parsley (Petroselinum crispum) against $\mathrm{CCl}_{4}$-induced oxidative stress in mouse testes and thyroid glands.

\section{Materials and Methods}

2.1. Plant Material. The fresh aerial parts of Parsley (Petroselinum crispum; family Apiaceae) were collected from the local farm of El-Sharqia Governorat, Egypt, during April 2019. The leaves were scientifically identified by a taxonomist in the herbarium of the Agricultural Museum, Giza (CAIM). A voucher specimen (CAIA 16472) was deposited at the herbarium of the Botany Department, College of Science, Ain Shams University.

2.2. Animals. Eight-week-old, twenty-four C57BL/6 adult male mice $(25 \sim 28 \mathrm{~g}$ ) were used in this study. The mice were maintained under standard conditions (temperature of $\left(\sim 20-22^{\circ} \mathrm{C}\right)$ with a $12 \mathrm{~h}$ light/dark cycle and $40-60 \%$ humidity and were provided with standard diet and water ad libitum. All experimental procedures were done in accordance with the protocol prescribed by a local ethics committee (Ref. No. KFU-REC/2021-07-01).

2.3. Chemical and Reagents. $\mathrm{CCl}_{4}$ was purchased from SigmaAldrich (St. Louis, MO, USA). Colorimetric assay kits of catalase (CAT; Cat. No.: CA 2516), superoxide dismutase (SOD; Cat. No.: SA 2520), and malondialdehyde (MDA; Cat. No.: MD 2528) were purchased from the Bio Diagnostic company, Giza, Egypt. The enzyme-linked immunosorbent assay (ELISA) kits of testosterone (Cat. No. MBS494055), triiodothyronine (T3; Cat. No. MBS732764), free triiodothyronine (fT3; MBS760765), thyroxine (T4; Cat. No. MBS700665), and free thyroxine (fT4; Cat. No. MBS726180) were purchased from My-Bio Source Company, San Diego, CA, USA. Thyroid-stimulating hormone (TSH; Cat. No. KT29922) ELISA kit was purchased from Kamiya Biomedical Company (Seattle, WA, USA). ELISA kits of follicle stimulating hormone (FSH; Cat. No. KA2330) and luteinizing hormone (LH; Cat. No. KA2332) were purchased from Novus Biologicals LLC (Centennial, CO, USA). All other reagents were of analytical grade.

2.4. Experimental Design. After 2 weeks of acclimatization, the animals were randomly divided into four groups (6 mice per group) and treated for 4 weeks as follows:

(1) Control group: administered $3 \mathrm{~mL} / \mathrm{kg}$ olive oil intraperitoneally, twice a week (Saturday and Wednesday), followed by intragastrically administration daily of $0.5 \mathrm{~mL} / \mathrm{kg}$ saline

(2) $\mathrm{CCl}_{4}$ group: administered intraperitoneally, $3 \mathrm{~mL} / \mathrm{kg}$ $\mathrm{CCl}_{4}$ (30\% in olive oil), twice a week (Saturday and Wednesday), dose was chosen according to previous studies [27-29]

(3) PO group: administered daily intragastrically PO $(0.5 \mathrm{~mL} / \mathrm{kg})$ according to Khalil et al. [21]

(4) $\mathrm{CCl}_{4}+\mathrm{PO}$ group: coadministrated $\mathrm{CCl}_{4}$ and PO at the aforementioned doses

2.5. Blood and Tissue Sampling. Twenty-four hours after the last treatment, the animals were anesthetized with diethyl 
ether and sacrificed by cutting the neck at the jugulars by a sharp razor blade. Blood was collected into clean test tubes without anticoagulants. The blood samples were then left to coagulate at $(22 \pm 2){ }^{\circ} \mathrm{C}$ and centrifuged at $2800 \mathrm{xg}$ for $10 \mathrm{~min}$. Serum was separated immediately and stored at $-80^{\circ} \mathrm{C}$ for future hormonal assays. Pieces of the thyroid glands and right testes were isolated and washed in icecold normal saline solution and kept at $-80^{\circ} \mathrm{C}$ for future analysis. Left testes were also isolated for the histological examination.

\subsection{Methodology}

2.6.1. Isolation of Petroselinum crispum Leaf Essential Oils. Petroselinum crispum leaves $(700 \mathrm{~g})$ were hydrodistilled in a cleveger-type apparatus [30]. After $4 \mathrm{~h}$ of hydrodistillation, the essential oils were recovered from water surface. The oils were then allowed to dry above anhydrous sodium sulphate and then stored in sealed dark glass vials and stored in refrigerator for additional experiments. GC-MS analysis was done by Hewlett-Packard 6890 gas chromatograph close fitting with a fused silica HP-5MS capillary column $(30 \mathrm{~m} \times 0.25 \mathrm{~mm}$; film thickness $0.25 \mu \mathrm{m}$ ). The temperature of oven was adjusted at $60^{\circ} \mathrm{C}$ at $3^{\circ} \mathrm{C} / \mathrm{min}$. Carrier gas was helium which was used at $2 \mathrm{~mL} / \mathrm{min}$ flow rate. The gas chromatograph was coupled with a Hewlett-Packard 6890 mass selective detector. The MS working parameters were ionization voltage, $70 \mathrm{eV}$, and ion source temperature $200^{\circ} \mathrm{C}$. Characterization and identification of essential oil constituents depend on their retention indices relative to n-alkanes and computer matching with the WILEY 275 Library and by comparison of the patterns of fragmentation of the mass spectra with those documented in the previous literature [31].

2.6.2. Assessment of Tissue Catalase and Superoxide Dismutase Activities and Malondialdehyde Levels. The thyroid gland and testis tissues were homogenized in $0.1 \mathrm{M}$ phosphate buffer. The homogenates were centrifuged at $2800 \mathrm{xg}$ and $4^{\circ} \mathrm{C}$ for $30 \mathrm{~min}$, and the supernatants were used for biochemical estimations. Catalase assay depends on the quantity of remaining hydrogen peroxide $\left(\mathrm{H}_{2} \mathrm{O}_{2}\right)$ after the action of CAT present in the sample. The rest of $\mathrm{H}_{2} \mathrm{O}_{2}$ reacts with 3,5-dichloro-2-hydroxybenzene sulfonic acid and 4aminophenazone to form colored chromophore which can be measured at $510 \mathrm{~nm}$. The color intensity is inversely proportional to the amount of catalase in the original sample [32]. SOD assay relies on the ability of the enzyme to inhibit the phenazine methosulphate-mediated reduction of nitroblue tetrazolium dye that was measured at $560 \mathrm{~nm}$ [33]. The principal of MDA assay is thiobarbituric acid (TBA) which reacts with MDA in acidic medium at temperature of $95^{\circ} \mathrm{C}$ for $30 \mathrm{~min}$ to form thiobarbituric acid reactive product, and the absorbance of the resultant pink product can be measured at $534 \mathrm{~nm}$ [34]. The protein content of the tissue samples was determined by the method described by Lowry et al. using bovine serum albumin as a standard [35].

2.6.3. Assessment of Thyroid Hormones in Serum. T3 ELISA kit utilized a polyclonal anti-T3 antibody and T3-HRP conjugate (T3-Horseradish Peroxidase Conjugate). The assay sample and buffer were incubated together with T3-HRP conjugate in precoated plate for one hour. Then, wells were decanted and washed five times and were incubated with a substrate for HRP enzyme. The reaction was stopped by stop solution addition to the formed blue colored complex which turned the solution yellow. The color intensity was measured spectrophotometrically at $450 \mathrm{~nm}$ in a microplate reader, and the T3 concentration in each sample is interpolated from this standard curve. The fT3 assay used competitive ELISA as the method where the microtiter plate provided was precoated with fT3. The sample or standard competes with a fixed amount of fT3 on the solid phase supporter for sites on the biotinylated antibody specific to fT3, and the excess conjugate and unbound sample or standard were washed from the plate. Then, HRP-Streptavidin (SABC) was added to each microplate well and incubated for 30 minutes at $37^{\circ} \mathrm{C}$. Then, a TMB $\left(3,3^{\prime}, 5,5^{\prime}\right.$-tetramethylbenzidine) substrate solution was added to each well for about 20 minutes at $37^{\circ} \mathrm{C}$. The reaction stopped by the addition of a sulphuric acid solution, and the color change is measured spectrophotometrically at a wavelength of $450 \mathrm{~nm}$. The concentration of fT3 in the samples was determined as compared to the optical density of the samples to the known concentration of the standard curve. As regards the T4 assay, ELISA kit used microtiter plate precoated with an antibody specific to T4 where standards or samples were added to the plate wells with biotin-conjugated T4 and incubated for one hour at $37^{\circ} \mathrm{C}$ then washed three times. After washing, avidinconjugated Horseradish Peroxidase (HRP) was added to the wells and incubated for 30 minutes at $37^{\circ} \mathrm{C}$. Substrate solution was added to the wells and incubated for 15 minutes at $37^{\circ} \mathrm{C}$, and the color developed was stopped, and the intensity of the color is measured at a wavelength of $450 \mathrm{~nm}$ in opposite to the amount of T4 in the sample that calculated as regards the standard. For the FT4 assay by ELISA kit, the assay sample and buffer were incubated together with FT4-HRP conjugate in precoated plate for one hour at $37^{\circ} \mathrm{C}$. After the incubation period, the wells were decanted and washed five times, then incubated with a substrate for HRP enzyme, and a blue-colored complex was formed and turned yellow by the addition of a stop solution, and the color intensity was measured spectrophotometrically at $450 \mathrm{~nm}$ in a microplate reader. The FT4 concentration in each sample is interpolated from the standard curve.

The TSH assay ELISA kit used antibody specific to TSH precoated microplate. A detection reagent was added to each well and was incubated for 1 hour at $37^{\circ} \mathrm{C}$. After incubation, the unbound conjugate is washed off. Next, avidin conjugated to Horseradish Peroxidase (HRP) was added to each microplate well and incubated for 30 minutes at $37^{\circ} \mathrm{C}$. Then, a substrate solution was added to each well and incubated for 15 minutes at $37^{\circ} \mathrm{C}$, and the color developed was stopped by the addition of stop solution, and the intensity of the color is measured at a wavelength of $450 \mathrm{~nm}$. Concentration was determined by using calibration curve on log-log or semilog graph paper, with the log of TSH concentration on the $y$-axis and absorbance on the $x$-axis, and the best fit straight line through the calibrator points was drawn and determined by regression analysis. 
2.6.4. Assessment of Testicular Hormones in Serum. Serum testosterone levels were measured using an ELISA kit. The principal is based on the competitive binding reaction between unknown hormone in our sample and known hormone sample conjugated to horseradish peroxidase (HRP). They compete for the binding sites of microplate wells coated with antitestosterone antibody. After one-hour incubation on a shaker $(600 \mathrm{rpm})$, the microplate is washed four times. Then, a substrate solution is added and is incubated in dark for 30 minutes, and reaction is stopped by stop solution, and the optical density was measured spectrophotometrically at $450 \mathrm{~nm}$. The concentration of testosterone $(\mathrm{pg} / \mathrm{mL})$ is calculated against reference stranded assayed in the same way.

The FSH assay is based on a solid phase enzyme-linked immunosorbent assay, where test sample is reacted with two antibodies, a rabbit polyclonal anti-rat FSH antibody for solid phase (microtiter wells) immobilization and a goat anti-rat FSH antibody in coupled to enzyme (horseradish peroxides) conjugate solution. FSH molecules were sandwiched between the solid phase and enzyme-linked antibodies for a 3-hour incubation period at $37^{\circ} \mathrm{C}$, then wells are washed for unbound labeled antibody removal. A color reagent solution is added and incubated for 20 minutes, developing a blue color that is stopped by addition of $2 \mathrm{~N}$ $\mathrm{HCl}$, and the intensity of the color formed is measured spectrophotometrically at $450 \mathrm{~nm}$. The concentration $(\mathrm{ng} / \mathrm{mL})$ of $\mathrm{LH}$ in sample was calculated in reference to a series of FSH standards assayed in the same way. While in LH assay like in FSH assay, test sample is reacted with two antibodies, a mouse anti-LH antibody for solid phase (microtiter wells) immobilization and mouse anti-LH antibody in the antibody-enzyme (horseradish peroxidase) conjugate solution. LH molecules sandwiched between the solid phase and enzyme-linked antibodies for a 2-hour incubation, then wells are washed with wash buffer to remove unbound labeled antibodies. A color reagent solution is added and incubated for 20 minutes, developing a blue color that is stopped by addition of $2 \mathrm{~N} \mathrm{HCl}$, and the intensity of the color formed is measured spectrophotometrically at $450 \mathrm{~nm}$. The concentration of $\mathrm{LH}(\mathrm{ng} / \mathrm{mL})$ in sample was calculated in reference to a series of LH standards assayed in the same way.

2.6.5. Assessment of Histological Alterations Using Light Microscopy. The testes were fixed in 10\% formaldehyde solution at $28^{\circ} \mathrm{C}$ for $24 \mathrm{~h}$, dehydrated, and embedded in paraffin wax. Thin sections were stained with conventional hematoxylin and eosin (H\&E) dye. The slides were examined using a standard light microscope (Nikon Corporation, Tokyo, Japan). Johnsen's tubular biopsy score (JTBS) [36] was used to evaluate the degree of testicular damage and maturity in 20 seminiferous tubules (magnification 400x) for each sample. In this respect, a numerical score of 1-10 was assigned to each seminiferous tubule indicating level of germinal epithelial maturation as follows: score (1), atrophic tubule; score (2), Sertoli cells without germ cells; score (3), only spermatogonia can be seen and no primary spermatocytes; score (4), few primary spermatocytes; score (5), many spermatocytes; score (6), few round spermatids; score (7), large
TABle 1: Chemical composition of parsley (Petroselinum crispum) leaf essential oil.

\begin{tabular}{lccc}
\hline $\begin{array}{l}\text { Retention } \\
\text { time }(\mathrm{min})\end{array}$ & Compounds & Area \% & Chemical class \\
\hline 25.34 & $1,3,8$-Mentha triene & 34.48 & Monoterpene \\
25.395 & Myristicin & 21.04 & Phenylpropene \\
25.530 & $\alpha$-Pinene & 4.61 & Monoterpene \\
25.578 & Elemicin & 2.89 & Phenylpropene \\
25.677 & Limonene & 3.23 & Monoterpene \\
25.754 & $\beta$-Pinene & 5.79 & Monoterpene \\
26.821 & Terpinolene & 1.75 & Monoterpene \\
27.832 & $\beta$-Phellandrene & 4.65 & Monoterpene \\
28.705 & Apiole & 18.08 & Phenylpropene \\
29.447 & Myrcene & 3.48 & Monoterpene \\
\hline
\end{tabular}

number of early spermatids without differentiation; score (8), few late spermatids; score (9), many late spermatids; and score (10), regular tubules with lots of sperm. Also, histomorphological analysis was assessed by measuring the diameter of 20 seminiferous tubules across the minor and major axes by using the imaging software (NIS-Elements, Tokyo, Japan), and the mean diameter was obtained. The tubular diameter was measured at magnification 400x. Round or nearly round tubules were randomly chosen.

2.7. Statistics. All data are expressed as means \pm standard error (SE). Statistical calculations were performed using Graph Pad Prism (version 3.00 for windows, GraphPad software, San Diego, CA, USA) The results were analyzed by one-way analysis of variance (ANOVA) for the comparison of the differences between the experimental groups followed by Tukey's post hoc test. The statistical level of significance was set at $p<0.05$.

\section{Results}

3.1. Identification of Chemical Composition of Parsley (Petroselinum crispum) Leaf Essential Oil. Hydrodistillation of the Petroselinum crispum leaves yielded $1.45 \%$ of clear yellowish liquid oil, where ten components, representing $100 \%$ of the total oil, were identified, and their percentages were calculated and are shown in Table 1 and Figure 1. The monoterpene components were $1,3,8$-mentha triene (34.48\%), $\beta$-pinene (5.79\%), $\beta$-phellandrene (4.65), $\alpha$ pinene (4.61\%), myrcene (3.48\%), limonene $(3.23 \%)$, and terpinolene $(1.75 \%)$. The phenylpropene compounds were myristicin $(21.04 \%)$, apiole (18.08\%), and elemicin (2.89\%).

\subsection{Antioxidant Effect of PO on Thyroid and Testicular} Tissues. The results in Table 2 revealed that mice intoxicated with $\mathrm{CCl}_{4}$ recorded a decrease in CAT and SOD enzyme activities and a significant increase in MDA levels in comparison with the control group corresponding values. Coadministration with $\mathrm{PO}$ markedly decreased the toxicity of $\mathrm{CCl}_{4}$ by significantly increasing the enzymatic activities of CAT and SOD and significantly decreasing MDA levels 


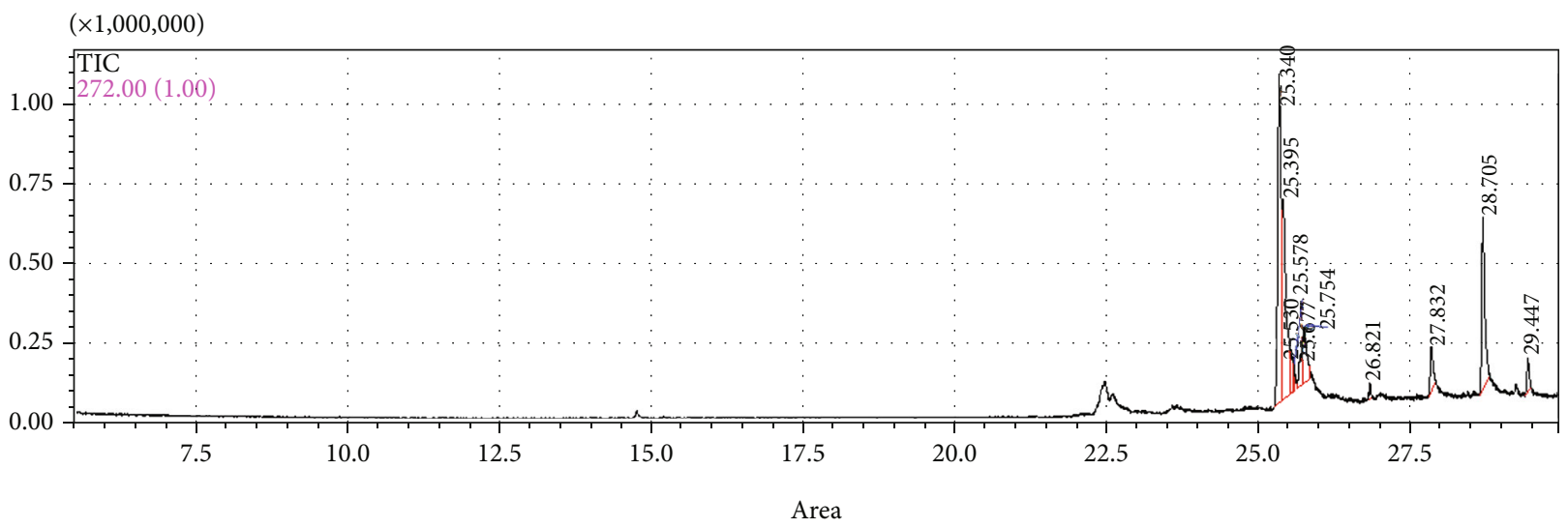

FIGURE 1: GC-MS chromatograph of parsley (Petroselinum crispum) leaf essential oil.

TABLE 2: Effect of oral administration of PO $(0.5 \mathrm{~mL} / \mathrm{kg})$ on thyroid and testicular tissues antioxidant parameters.

\begin{tabular}{lcccccc}
\hline \multirow{2}{*}{ Groups } & \multicolumn{2}{c}{ CAT (U/mg protein) } & \multicolumn{2}{c}{ Parameter } & \multicolumn{2}{c}{ MDA (nmol/g tissue) } \\
& \multicolumn{2}{c}{ Testis } & Thyroid & Testis & Thyroid & \multicolumn{2}{c}{ Testis } & Thyroid \\
\hline Control & $34.58 \pm 0.39^{\mathrm{a}}$ & $23.62 \pm 0.76^{\mathrm{a}}$ & $63.30 \pm 0.48^{\mathrm{a}}$ & $42.35 \pm 0.54^{\mathrm{a}}$ & $8.76 \pm 0.18^{\mathrm{a}}$ & $7.183 \pm 0.18^{\mathrm{a}}$ \\
$\mathrm{CCl}_{4}$ & $15.08 \pm 0.29^{\mathrm{b}}$ & $8.833 \pm 0.27^{\mathrm{b}}$ & $20.43 \pm 0.17^{\mathrm{b}}$ & $17.98 \pm 0.26^{\mathrm{b}}$ & $31.07 \pm 0.47^{\mathrm{b}}$ & $21.02 \pm 0.47^{\mathrm{b}}$ \\
$\mathrm{PO}$ & $33.68 \pm 0.39^{\mathrm{a}}$ & $23.03 \pm 0.41^{\mathrm{a}}$ & $62.28 \pm 0.50^{\mathrm{a}}$ & $41.2 \pm 0.60^{\mathrm{a}}$ & $9.12 \pm 0.34^{\mathrm{a}}$ & $6.707 \pm 0.16^{\mathrm{a}}$ \\
$\mathrm{CCl}_{4}+\mathrm{PO}$ & $22.12 \pm 0.57^{\mathrm{c}}$ & $13.13 \pm 0.48^{\mathrm{c}}$ & $35.68 \pm 0.53^{\mathrm{c}}$ & $25.85 \pm 0.22^{\mathrm{c}}$ & $18.05 \pm 0.37^{\mathrm{c}}$ & $12.67 \pm 0.39^{\mathrm{c}}$ \\
\hline
\end{tabular}

Data are expressed as mean \pm SE. Different superscript letters within the same column are significantly different $(p<0.05)$.

toward the $\mathrm{CCl}_{4}$ group corresponding values. The group treated with $\mathrm{PO}$ alone showed not statistical differences in the detected parameters levels as compared to their corresponding control group.

3.3. Ameliorative Effect of PO on Thyroid Hormones. Figure 2 shows a significant decrease in T3, fT3, T4, fT4, and TSH levels in mice treated with $\mathrm{CCl}_{4}$ when compared to the control values. Compared to the $\mathrm{CCl}_{4}$ and control groups, the group administered with $\mathrm{CCl}_{4}$ and $\mathrm{PO}$ showed significant elevations and reductions in the levels of thyroid hormones, respectively. However, the thyroid hormones assayed in PO group recorded not statistical differences from their corresponding control group.

3.4. Modulatory Effect of PO on Testicular Hormones. Figure 3 represented the significant decrement effect of $\mathrm{CCl}_{4}$ administration in $\mathrm{CCl}_{4}$ group in the levels of testosterone, $\mathrm{FSH}$, and $\mathrm{LH}$. The group treated with $\mathrm{CCl}_{4}$ and $\mathrm{PO}$ showed a significant increase in these levels compared to the $\mathrm{CCl}_{4}$ group but showed a significant decrease when compared to the control group. The PO-treated group showed no changes when compared to the control group.

3.5. Protective Effect of $P O$ on Testis Histology. Figure 4 shows the histoarchitecture (a, b, and c), histopathological scoring (d), and the histomorphological diameter of seminiferous tubules (e) of testes. The control group exhibited regular and normal seminiferous tubules and a normal spermatogenesis series (a). $\mathrm{CCl}_{4}$ treatment resulted in hypospermatogen- esis within irregular-shaped seminiferous tubules. Further, this group showed notable germinal cell destruction compared to the control group. In addition, the testicular tissue sections exhibited desquamation and vacuolization in the germinal epithelium with prominent edema in the interstitial spaces (b). Conversely, the effects on the seminiferous tubule structure were ameliorated in the group treated with $\mathrm{CCl} 4$ and $\mathrm{PO}$, in addition to improvement in the spermatogenesis series. However, some detachments in the seminiferous epithelium, edema, and congestion were still detected in the testicular tissues of this group (c). The mean testicular spermatogenesis scores by JTBS (d) values were compared among groups. The mean of JTBS was 3.2 in $\mathrm{CCl}_{4}$ group that was significantly lower than the value in control group (9.5), indicating atrophy and hypospermatogenesis, while the coadministration with PO significantly increased JTBS values (5.8) as compared to that recorded in $\mathrm{CCl}_{4}$ group. The results of the histomorphological seminiferous tubule diameter means (e) were compared among groups. The $\mathrm{CCl}_{4}$ group showed $121.4 \mu \mathrm{m}$ diameter which is significantly lower than that of control group $(144.1 \mu \mathrm{m})$, while coadministration with PO recorded significantly increased mean of tubule diameter values $(136.7 \mu \mathrm{m})$ as compared to the $\mathrm{CCl}_{4}$ group value.

\section{Discussion}

It is well known that $\mathrm{CCl} 4$ is a potent hepatotoxin and used to induce acute liver injury in experimental animal models by mechanisms involving oxidative stress, lipid peroxidation in the hepatocyte membrane, inflammatory responses, and 


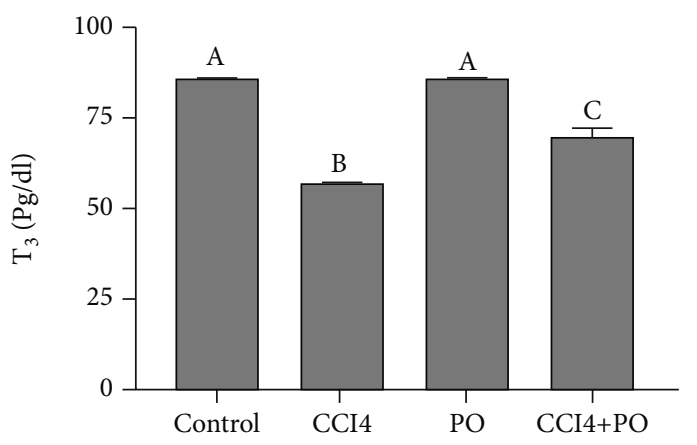

(a)

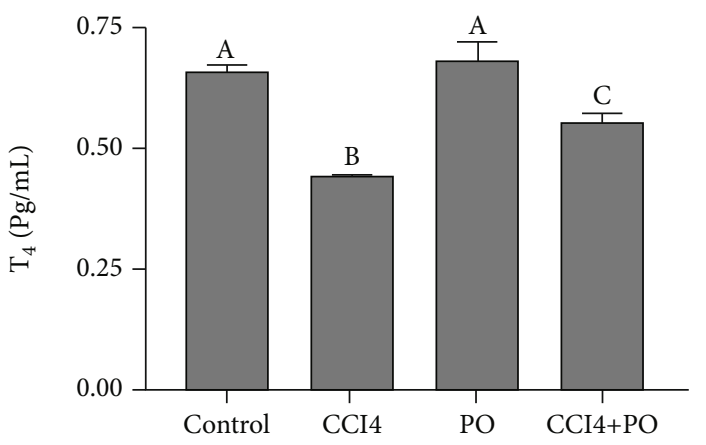

(c)

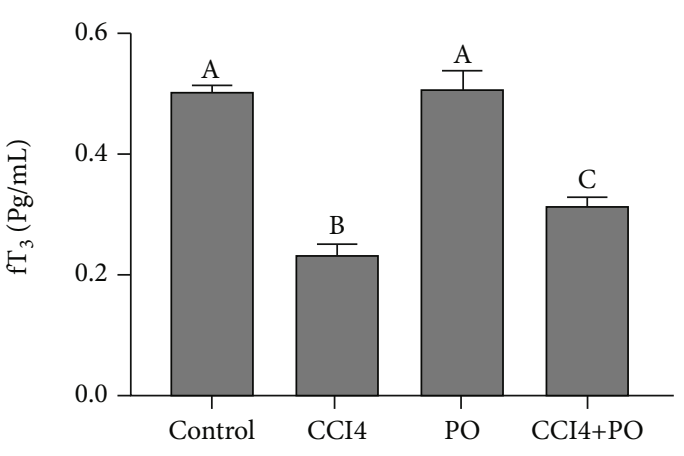

(b)

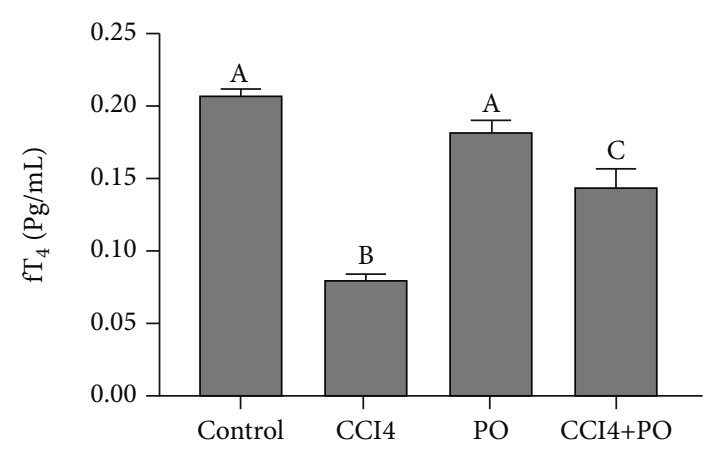

(d)

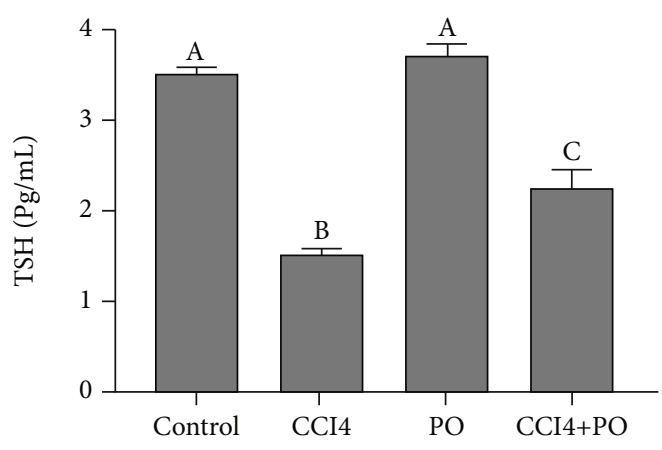

(e)

Figure 2: Effect of oral administration of PO $(0.5 \mathrm{~mL} / \mathrm{kg})$ on the thyroid gland hormone profile in mice intoxicated with $\mathrm{CCl}{ }_{4} ; n=6$. $(\mathrm{a}) \mathrm{T} 3$, (b) fT3, (c) T4, (d) fT4, and (e) TSH. Results are expressed as mean \pm SE. Bars with different letters are significantly different $(p<0.05)$ between groups.

hepatocyte apoptosis and necrosis [37]. The present study results revealed the $\mathrm{CCl}_{4}$ induction of the oxidative stress status through the altered cellular redox balance in both testicular and thyroid tissues. There is a recorded significant reduction of the antioxidant enzyme activities of SOD and CAT, where SOD catalyzes the dismutation of superoxide radical into oxygen and hydrogen peroxide and CAT catalyzes the decomposition of hydrogen peroxide to water and oxygen, in addition to the significant elevated levels of the lipid peroxidation marker, MDA, in the aforementioned tissues. Hence, the enhanced lipid peroxidation and reduced antioxidant enzyme activities lead to increased accumulation of superoxide radicals which additionally stimulate more lipid peroxidation. This oxidative stress status was previously confirmed through conversion of $\mathrm{CCl} 4$ to free radicals through cytochrome P450 enzymes that induce a chain reac- tion causing lipid peroxidation in the cell membrane, mitochondria, and endoplasmic reticulum, as well as membrane oxidative phosphorylation, which triggers cellular apoptosis and necrosis $[38,39]$. The imbalance between the free radicals and the antioxidant defense system which induced damage in the nucleic acids, proteins, and lipids present in the sperm membrane was reviewed, where the structural integrity of the sperm membrane maintained by cholesterol and phospholipids and possesses a large quantity of polyunsaturated fatty acids that make the sperm highly vulnerable to oxidative stress. In addition the low concentrations of antioxidant enzymes like catalases and dismutases, the sperm plasma membrane leads it to be susceptible to the attack of the free radicals triggering alterations in the membrane permeability for entrance of cations into the sperm, shifting its osmolarity, and leading to formation of soluble calcium 


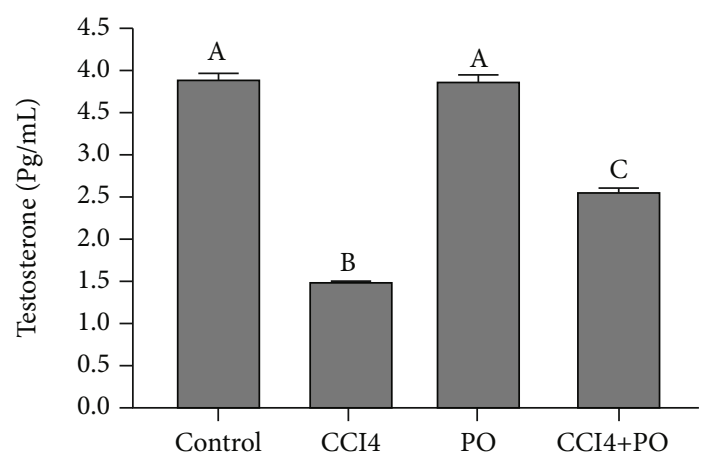

(a)

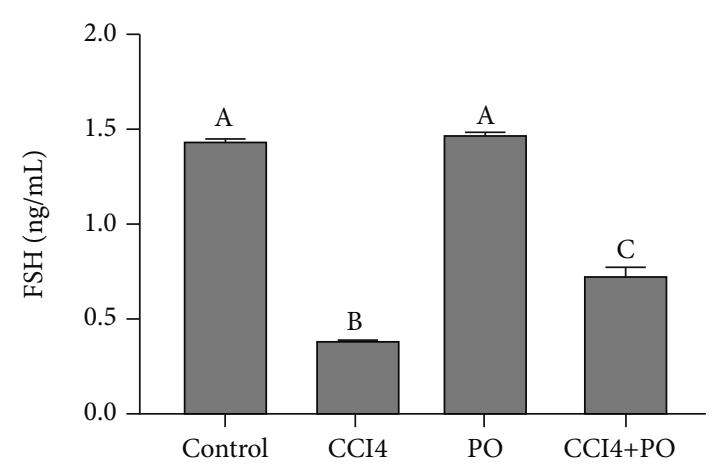

(b)

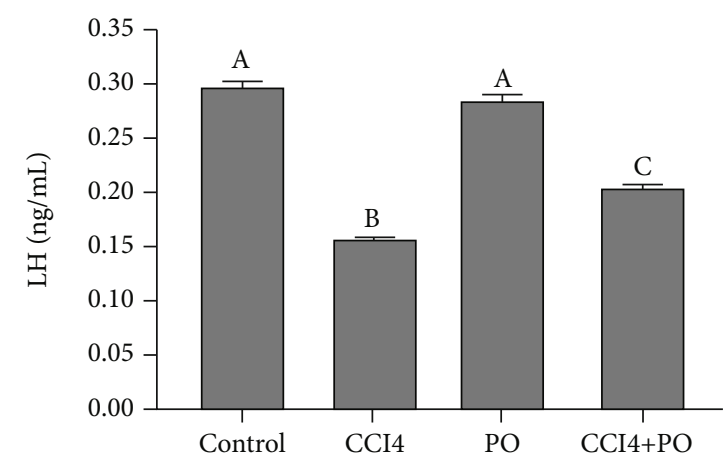

(c)

FIGURE 3: Effect of oral administration of $\mathrm{PO}(0.5 \mathrm{~mL} / \mathrm{kg})$ on the testicular hormone profile in mice intoxicated with $\mathrm{CCl} 4{ }_{4} ; n=6$ per group. (a) Testosterone, (b) FSH, and (c) LH. Results are expressed as mean \pm SE. Bars with different letters are significantly different $(p<0.05)$ between groups.

phosphates, depletion of ATP, and activation of proteolytic and phosphoglycolytic enzymes. In addition, such damages lactate dehydrogenase, pyruvate kinase, glyceraldehyde 3 phosphate dehydrogenase, and ATPase enzymes that leads to loss or decreases in sperm mobility, protein and lipid damage, DNA alterations, anomalies in its morphology, fertility problems, and cell death [40]. That is in line with the present study result consequence in the demonstrated significant decrease in testosterone, FSH, and LH levels in the $\mathrm{CCl} 4$ group. And the histopathological examination of the testicular tissue in $\mathrm{CCl}_{4}$ group revealed hypospermatogenesis (JTBS), reduced diameter of seminiferous tubules, and destructed germinal cells compared to the control group. Hypogonadism effect as a result of CCl4-induced oxidative stress may be due to the direct toxicity of $\mathrm{CCl} 4$ on the Leydig cell membrane and central nervous system or due to its indirect effect on the hypothalamic-pituitary-gonadal axis as previously discussed in many studies [19, 41-46].

The thyroid gland oxidative stress status and the hypothyroidism predicted by the decreased T4, T3, fT4, fT3, and TSH levels in the CCl4 group in the present study are in agreement with the thyroid gland malfunction due to $\mathrm{CCl} 4$ intoxication previously evaluated in different experimental studies, where $\mathrm{CCl} 4$ increased lipid peroxidation and decreased the level of antioxidant enzymes in thyroid tissue, and the serum levels of thyroid hormones are affected by mechanisms that interfere with the hepatic metabolism of thyroid hormones, i.e., via suppressing the activity of outer ring deiodine enzyme that converts $\mathrm{T}_{4}$ into the biologically active $T_{3}$ form in liver microsomes, and $\mathrm{CCl}_{4}$ may directly affect pituitary-thyroid axis hormones $[10,19,27,47-52]$.

The chemical compositions of parsley oil are previously evaluated in many studies from different plant varieties and seasonal variations by different extraction methods that could affect the content percentage of the identified compounds. The main separated components in the present results were 1,3,8-mentha triene, myristicin, and apiole, that monoterpene and phenylpropene compounds are consistent with previous studies as main compounds with antioxidant activities [53-56]. The compounds making the greatest contributions to characteristic parsley odor are 1,3,8-mentha triene and apiole. Myristicin, apiole, $\alpha$-pinene, and $\beta$-penene scavenge free radicals and induce antioxidant enzyme production in cells, thus protecting against ROS generated by CCl4-induction $[23,53,55,57,58]$. In addition, PO may stimulate the synthesis of glutathione, which is a crucial nonenzymatic antioxidant [59]. The antioxidant activity has been confirmed using the 1,1-diphenyl-2-picrylhydrazyl $(\mathrm{DPPH})$ radical scavenging and $\beta$-carotene-linoleate bleaching assays as well as Ferric reducing capacity method [55, 60] Hence, the presence of bioactive compounds may be a key factor in reducing the free radicals, where PO coadministration with $\mathrm{CCl} 4$ impedes oxidation in testicular and thyroid tissues through the recorded significantly increased enzymatic activities of CAT and SOD and decreased MDA 


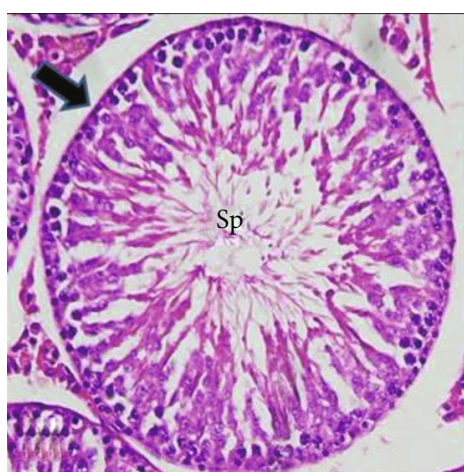

(a)

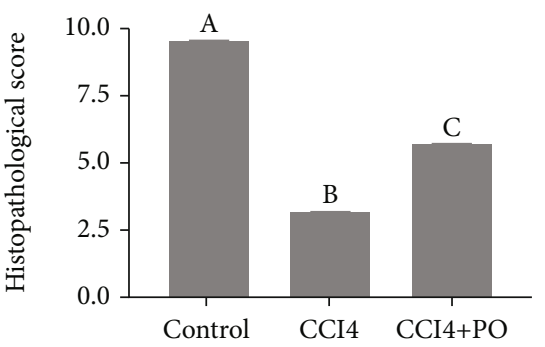

(d)

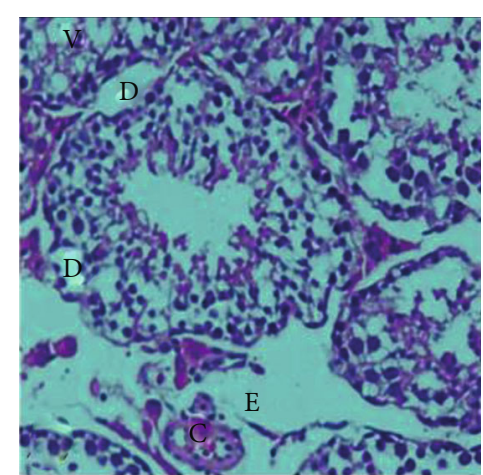

(b)

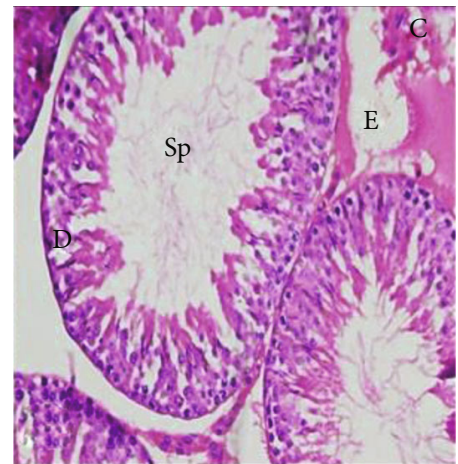

(c)

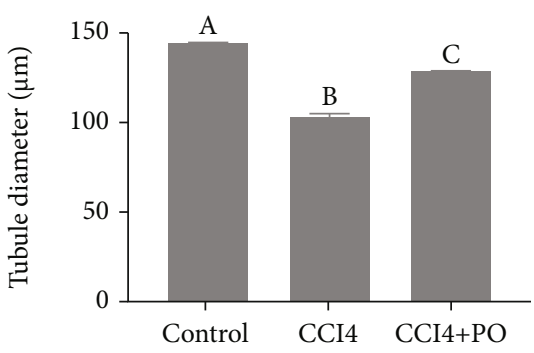

(e)

FIGURE 4: Light micrographs of testicular tissues of the experimental groups represented in (a-c). Control group (a) exhibiting regular seminiferous tubule (arrow) with normal spermatogenesis series (Sp). $\mathrm{CCl}_{4}$ group (b) demonstrating irregular and marked damage of seminiferous tubules, desquamation (D), edema (E), vacuolization (V), and congestion (C). $\mathrm{CCl}_{4}+\mathrm{PO}$ (c) showing histological improvements. Hematoxylin and eosin staining with original magnification 400x. (d) Johnsen's tubular biopsy score (JTBS), and the histomorphological diameter of seminiferous tubules $(\mu \mathrm{m})$ were represented in (e). Bars with different letters are significantly different $(p<0.05)$ between groups.

levels in the testicular and thyroid tissues as compared to CCl4 group. Antioxidant enzymes play key roles in the detoxification of free radicals and ROS produced during exposure to toxic chemicals, including the metabolism of various xenobiotics such as $\mathrm{CCl} 4$ [27]. Also, previous studies reported that antioxidant compounds can protect the testis tissue against apoptosis and prevention of lipid peroxidation $[61,62]$. In addition, PO may stimulate the synthesis of glutathione, which is a crucial nonenzymatic antioxidant [59].

A significant improvement was observed in thyroid and testicular hormone profiles of the group coadministered with $\mathrm{PO}$ and $\mathrm{CCl} 4$ compared to that of the $\mathrm{CCl} 4$ group by their significant increase and evaluated through the histological improvement of the testicular tissue. In agreement with the study of Razooqi et al. [63], they reported that PO has a protective role against heat stress-induced damage to the testes of Japanese quail. Moreover, the ameliorative effect of parsley on thyroid gland dysfunction has been linked to its antioxidant effects or indirectly via its hepatoprotective effect as PO coadministration attenuated thyroid hormone metabolic disturbances associated with liver injury induced $[49,59,64,65]$. In addition, PO was therapeutically recommended in a previous study in hypothyroidism mice model via its elevating effect on thyroid hormones and the histopathological evidenced recovery of thyroid parenchyma [64] as regards the effect of thyroid hormones on different cell types in the testes, such as the Leydig cells, Sertoli cells, and germ cells, with $\mathrm{T} 3$ regulating testicular growth and maturation [65]. Thyroid hormone receptors have been identified in the testes; therefore, thyroid hormones are considered to have key roles in male reproductive functions [66, 67]. In addition, Badr et al.'s study showed that testicular damage caused by cadmium in rats can be improved by reversing the hypothyroid status via treatment with quercetin, a natural antioxidant [68]. Moreover, recent study showed that natural antioxidants alleviated testicular toxicity in rats with hypothyroidism [69].

\section{Conclusion}

The present study results recommended that the natural antioxidant and parsley essential oil administration via its constituents could induce amelioration of thyroid hormone levels and improvement in the testicular injury in mice intoxicated by $\mathrm{CCl}$. Meanwhile, further studies are required for the evaluation of PO activities which missed in the present study including the evaluation of more parameters of the antioxidant system and the molecular basis of these protective and therapeutic effects in testicular tissue.

\section{Data Availability}

The data used to support the findings of the study are available from the corresponding author upon request. 


\section{Conflicts of Interest}

The authors declare that there are no conflicts of interest.

\section{Authors' Contributions}

All authors contributed to the design and implementation of the research, formal analysis and investigation of the results, and writing of the manuscript.

\section{Acknowledgments}

The authors are thankful to the Biological Sciences Department, Science College, King Faisal University, for providing the necessary facilities. Many thanks to Dr. Heba Ibrahim Abd El-Moaty, professor in Medicinal and Aromatic Plants Department, Desert Research Center El-Mataria, Cairo, Egypt, for her technical help regarding the isolation of essential oil.

\section{References}

[1] R. J. Aitken and S. D. Roman, "Antioxidant systems and oxidative stress in the testes," Oxidative Medicine and Cellular Longevity, vol. 1, no. 1, p. 24, 2008.

[2] L. Yang, Y. Chen, Y. Liu et al., "The role of oxidative stress and natural antioxidants in ovarian aging," Frontiers in Pharmacology, vol. 11, article 617843, 2021.

[3] V. Lobo, A. Patil, A. Phatak, and N. Chandra, "Free radicals, antioxidants and functional foods: impact on human health," Pharmacognosy Reviews, vol. 4, no. 8, pp. 118-126, 2010.

[4] J. Bouayed and T. Bohn, "Exogenous antioxidants-doubleedged swords in cellular redox state: health beneficial effects at physiologic doses versus deleterious effects at high doses," Oxidative Medicine and Cellular Longevity, vol. 3, no. 4, p. $237,2010$.

[5] T. T. Turner and J. J. Lysiak, "Oxidative stress: a common factor in testicular dysfunction," Journal of Andrology, vol. 29, no. 5, pp. 488-498, 2008.

[6] J. B. Anderson and R. C. Williamson, "Fertility after torsion of the spermatic cord," British Journal of Urology, vol. 65, no. 3, pp. 225-230, 1990.

[7] R. Smith, H. Kaune, D. Parodi et al., "Increased sperm DNA damage in patients with varicocele: relationship with seminal oxidative stress," Human Reproduction (Oxford, England), vol. 21, no. 4, pp. 986-993, 2006.

[8] S. B. Guimarães, A. A. Aragão, J. M. Santos, O. Kimura, P. H. Barbosa, and P. R. Vasconcelos, "Oxidative stress induced by torsion of the spermatic cord in young rats," Acta cirurgica brasileira, vol. 22, no. 1, pp. 30-33, 2007.

[9] S. K. Chakrabarti, S. Ghosh, S. Banerjee, S. Mukherjee, and S. Chowdhury, "Oxidative stress in hypothyroid patients and the role of antioxidant supplementation," Indian journal of endocrinology and metabolism, vol. 20, no. 5, pp. 674-678, 2016.

[10] R. Malik and H. Hodgson, "The relationship between the thyroid gland and the liver," QJM, vol. 95, no. 9, pp. 559-569, 2002.

[11] M. Abalovich, O. Levalle, R. Hermes et al., "Hypothalamicpituitary-testicular axis and seminal parameters in hyperthyroid males," Thyroid, vol. 9, no. 9, pp. 857-863, 1999.
[12] D. K. Sahoo, A. Roy, S. Chattopadhyay, and G. B. Chainy, "Effect of T3 treatment on glutathione redox pool and its metabolizing enzymes in mitochondrial and postmitochondrial fractions of adult rat testes," Indian Journal of Experimental Biology, vol. 45, no. 4, pp. 338-346, 2007.

[13] M. Manno, M. Rezzadore, M. Grossi, and C. Sbrana, "Potentiation of occupational carbon tetrachloride toxicity by ethanol abuse," Human \& Experimental Toxicology, vol. 15, no. 4, pp. 294-300, 1996.

[14] S. Szymonik-Lesiuk, G. Czechowska, M. Stryjecka-Zimmer et al., "Catalase, superoxide dismutase, and glutathione peroxidase activities in various rat tissues after carbon tetrachloride intoxication," Journal of Hepato-Biliary-Pancreatic Surgery, vol. 10, no. 4, pp. 309-315, 2003.

[15] M. K. Manibusan, M. Odin, and D. A. Eastmond, "Postulated carbon tetrachloride mode of action: a review," Journal of Environmental Science and Health, Part C, vol. 25, no. 3, pp. 185-209, 2007.

[16] M. R. Khan, W. Rizvi, G. N. Khan, R. A. Khan, and S. Shaheen, "Carbon tetrachloride-induced nephrotoxicity in rats: protective role of _Digera muricata_," Journal of Ethnopharmacology, vol. 122, no. 1, pp. 91-99, 2009.

[17] M. M. Rahman, A. Y. Muse, D. Khan et al., "Apocynin prevented inflammation and oxidative stress in carbon tetra chloride induced hepatic dysfunction in rats," Biomedicine of Pharmacotherapy, vol. 92, pp. 421-428, 2017.

[18] V. Unsal, M. Cicek, and İ. Sabancilar, "Toxicity of carbon tetrachloride, free radicals and role of antioxidants," Reviews on environmental health, vol. 36, no. 2, pp. 279-295, 2021.

[19] M. R. Khan and D. Ahmed, "Protective effects of _Digera muricata_(L.) Mart. on testis against oxidative stress of carbon tetrachloride in rat," Food and Chemical Toxicology: An International Journal Published for the British Industrial Biological Research Association, vol. 47, no. 6, pp. 1393-1399, 2009.

[20] S. A. Abdellatief, A. A. Galal, S. M. Farouk, and M. M. AbdelDaim, "Ameliorative effect of parsley oil on cisplatin-induced hepato-cardiotoxicity: a biochemical, histopathological, and immunohistochemical study," Biomedicine \& Pharmacotherapy, vol. 86, pp. 482-491, 2017.

[21] A. F. Khalil, H. O. Elkatry, and H. F. El Mehairy, "Protective effect of peppermint and parsley leaves oils against hepatotoxicity on experimental rats," Annals of Agricultural Sciences, vol. 60, no. 2, pp. 353-359, 2015.

[22] J. E. Simon and J. Quinn, "Characterization of essential oil of parsley," Journal of Agricultural and Food Chemistry, vol. 36, no. 3, pp. 467-472, 1988.

[23] G.-q. Zheng, P. M. Kenney, J. Zhang, and L. K. T. Lam, "Inhibition of benzo[a]pyrene-induced tumorigenesis by myristicin, a volatile aroma constituent of parsley leaf oil," Carcinogenesis, vol. 13, no. 10, pp. 1921-1923, 1992.

[24] G. Badr, H. Elsawy, M. A. Amalki, M. Alfwuaires, M. S. A. elGerbed, and A. M. Abdel-Moneim, "Protective effects of myristicin against ulcerative colitis induced by acetic acid in male mice," Food and Agricultural Immunology, vol. 31, no. 1, pp. 435-446, 2020.

[25] B. Salehi, S. Upadhyay, I. Erdogan Orhan et al., "Therapeutic potential of $\alpha$ - and $\beta$-pinene: a miracle gift of nature," Biomolecules, vol. 9, no. 11, p. 738, 2019.

[26] D. Roberto, P. Micucci, T. Sebastian, F. Graciela, and C. Anesini, "Antioxidant activity of limonene on normal murine lymphocytes: relation to $\mathrm{H} 2 \mathrm{O} 2$ Modulation and cell 
proliferation," Basic \& Clinical Pharmacology \& Toxicology, vol. 106, no. 1, pp. 38-44, 2009.

[27] R. A. Khan, "Protective effects of Sonchus asper (L.) Hill, (Asteraceae) against $\mathrm{CCl}_{4}$-induced oxidative stress in the thyroid tissue of rats," BMC Complementary and Alternative Medicine, vol. 12, no. 1, 2012.

[28] D. T. P. Lien, C. T. K. Hoang, N. T. Hanh, D. X. Chu, P. T. B. Tram, and H. T. Toan, "Hepatoprotective effect of silymarin on chronic hepatotoxicity in mice induced by carbon tetrachloride," Journal of Pharmacognosy and Phytochemistry, vol. 5, pp. 262-266, 2016.

[29] H. Elsawy, G. M. Badr, A. Sedky, B. M. Abdallah, A. M. Alzahrani, and A. M. Abdel-Moneim, "Rutin ameliorates carbon tetrachloride (CCl4)-induced hepatorenal toxicity and hypogonadism in male rats," PeerJ, vol. 7, article e7011, 2019.

[30] E. F. K. Denny, "Hydrodistillation of oils from aromatic herbs," Perfumer \& flavoris, vol. 14, pp. 57-63, 1989.

[31] R. P. Adams, Identification of Essential Oil Components by Gas Chromatography, Quadrupole Mass Spectroscopy, Allured Pub. Corporation, Carol Stream, Ill, 3rd edition, 2001.

[32] H. Aebi, "Catalase in vitro," Methods in Enzymology, vol. 105, pp. 121-126, 1984.

[33] M. Nishikimi, N. Appaji Rao, and K. Yagi, "The occurrence of superoxide anion in the reaction of reduced phenazine methosulfate and molecular oxygen," Biochemical and Biophysical Research Communications, vol. 46, no. 2, pp. 849-854, 1972.

[34] H. Ohkawa, N. Ohishi, and K. Yagi, “Assay for lipid peroxides in animal tissues by thiobarbituric acid reaction," Analytical Biochemistry, vol. 95, no. 2, pp. 351-358, 1979.

[35] O. H. Lowry, N. J. Rosebrough, A. L. Farr, and R. J. Randall, "Protein measurement with the Folin phenol reagent," Journal of Biological Chemistry, vol. 193, no. 1, pp. 265-275, 1951.

[36] S. G. Johnsen, "Testicular biopsy score Count - A method for registration of spermatogenesis in human testes: normal values and results in 335 hypogonadal males," Hormones, vol. 1, no. 1, pp. 2-25, 2004.

[37] X. Li, X. Liu, Y. Zhang et al., "Hepatoprotective effect of apolipoprotein A4 against carbon tetrachloride induced acute liver injury through mediating hepatic antioxidant and inflammation response in mice," Biochemical and Biophysical Research Communications, vol. 534, pp. 659-665, 2021.

[38] S. Bisht, M. Faiq, M. Tolahunase, and R. Dada, "Oxidative stress and male infertility," Urology, vol. 14, no. 8, pp. 470485, 2017.

[39] J. Gosalvez, E. Tvrda, and A. Agarwal, "Free radical and superoxide reactivity detection in semen quality assessment: past, present, and future," Journal of Assisted Reproduction and Genetics, vol. 34, no. 6, pp. 697-707, 2017.

[40] A. C. Izquierdo, A. E. I. Reyes, A. R. O. Muñiz et al., "Effect of oxidative stress on sperm cells," in Glutathione System and Oxidative Stress in Health and Disease, IntechOpen, 2020.

[41] R. J. Aitken, T. B. Smith, M. S. Jobling, M. A. Baker, and G. N. De Iuliis, "Oxidative stress and male reproductive health," Asian Journal of Andrology, vol. 16, no. 1, pp. 31-38, 2014.

[42] F. Rafiee, V. Nejati, R. Heidari, and H. Ashraf, "Protective effect of methanolic extract of Berberis integerrima Bunge. root on carbon tetrachloride-induced testicular injury in Wistar rats," International Journal of Reproductive Biomedicine, vol. 14, no. 2, pp. 133-140, 2016.

[43] F. Tabassum and M. R. Khan, "Prevention of CCl4 induced hypogonadism with Raphanus sativus seeds in rat," Pakistan
Journal of Pharmaceutical Sciences, vol. 30, no. 2, pp. 375380, 2017.

[44] M. Mazani, M. Ojarudi, S. Banaei et al., "The protective effect of cinnamon and ginger hydro-alcoholic extract on carbon tetrachloride-induced testicular damage in rats," Andrologia, vol. 52, no. 7, article e13651, 2020.

[45] A. K. Hadi, A. K. Obeid, and H. A. A.-A. Alsalame, “The protective effect of aqueous of Hylocereus polyrhizus fruits on some histological changes of the testes of treated male rats carbon tetrachloride," Annals of the Romanian Society for Cell Biology, vol. 25, no. 3, pp. 8161-8169, 2021.

[46] Z. Keshtmand, M. Akbaribazm, Y. Bagheri, and R. Oliaei, "The ameliorative effects of Lactobacillus coagulans and Lactobacillus casei probiotics on CCl4-induced testicular toxicity based on biochemical, histological and molecular analyses in rat," Andrologia, vol. 53, no. 1, article e13908, 2021.

[47] J. Leghait, V. Gayrard, N. Picard-Hagen et al., "Fipronilinduced disruption of thyroid function in rats is mediated by increased total and free thyroxine clearances concomitantly to increased activity of hepatic enzymes," Toxicology, vol. 255, no. 1-2, pp. 38-44, 2009.

[48] A. H. Moustafa, E. M. Ali, T. M. Mohamed, and H. I. Abdou, "Oxidative stress and thyroid hormones in patients with liver diseases," European Journal of Internal Medicine, vol. 20, no. 7, pp. 703-708, 2009.

[49] N. Abdel Aziz, "Disturbances in pituitary-thyroid axis hormones in rats exposed to CCL4 and/ or gamma-irradiation," Egyptian Journal of Radiation Sciences and Applications, vol. 26, no. 1, pp. 85-97, 2013.

[50] K. Naz, M. R. Khan, N. A. Shah, S. Sattar, F. Noureen, and M. L. Awan, "Pistacia chinensis: a potent ameliorator of CCl4 induced lung and thyroid toxicity in rat model," BioMed Research International, vol. 2014, Article ID 192906, 13 pages, 2014.

[51] A. Khan, B. Shal, M. Naveed et al., "Matrine ameliorates anxiety and depression-like behaviour by targeting hyperammonemia-induced neuroinflammation and oxidative stress in CCl4 model of liver injury," Neurotoxicology, vol. 72, pp. 38-50, 2019.

[52] N. Abdel-Aziz, "Disturbances in thyroid hormone metabolism in rats exposed to $\gamma$-radiation and carbon tetrachloride: the role of N-acetyl cysteine and sodium selenite," Egyptian Journal of Radiation Sciences and Applications, vol. 33, no. 2, pp. 119-131, 2020.

[53] H. Zhang, F. Chen, X. Wang, and H.-Y. Yao, "Evaluation of antioxidant activity of parsley (Petroselinum crispum) essential oil and identification of its antioxidant constituents," Food Research International, vol. 39, no. 8, pp. 833-839, 2006.

[54] M. Viuda-Martos, M. A. Mohamady, J. Fernández-López et al., "In vitro antioxidant and antibacterial activities of essentials oils obtained from Egyptian aromatic plants," Food Control, vol. 22, no. 11, pp. 1715-1722, 2011.

[55] I. Marín, E. Sayas-Barberá, M. Viuda-Martos, C. Navarro, and E. Sendra, "Chemical composition, antioxidant and antimicrobial activity of essential oils from organic fennel, parsley, and lavender from Spain," Foods, vol. 5, no. 4, p. 18, 2016.

[56] O. T. Okan, A. Kilic, A. Onaran, M. Öz, and İ. Deniz, "Endüstriyel ölçekte üretilen Nar (Punica granatum L.) ve Maydanoz (Petroselinum crispum) tohumu yağının kimyasal bileşimi, antioksidan ve antifungal özelliklerinin belirlenmesi," Artvin Çoruh Üniversitesi Orman Fakültesi Dergisi, vol. 21, no. 2, pp. 1-11, 2020. 
[57] S. E. Nielsen, J. F. Young, B. Daneshvar et al., "Effect of parsley (Petroselinum crispum) intake on urinary apigenin excretion, blood antioxidant enzymes and biomarkers for oxidative stress in human subjects," The British Journal of Nutrition, vol. 81, no. 6, pp. 447-455, 1999.

[58] S. Fejes, A. Blázovics, É. Lemberkovics, G. Petri, É. Szöke, and Á. Kéry, "Free radical scavenging and membrane protective effects of methanol extracts from Anthriscus cerefolium L. (Hoffm.) and Petroselinum crispum (Mill.) nym. ex A.?W. Hill," Phytotherapy Research, vol. 14, no. 5, pp. 362-365, 2000.

[59] A. Elkomy, M. Aboubakr, F. Elsayed, and Y. Medhat, "Protective effect of cinnamon and/or parsley oils against carbon tetrachloride (CCl4) induced hepatotoxicity in rats," Journal of Pharmacology \& Clinical Research, vol. 8, no. 1, article 555734, 2020.

[60] A. Farouk, H. Ali, A. R. Al-Khalifa, M. Mohsen, and R. Fikry, "Aroma volatile compounds of parsley cultivated in the Kingdom of Saudi Arabia and Egypt extracted by hydrodistillation and headspace solid-phase microextraction," International Journal of Food Properties, vol. 20, Supplement 3, pp. S2868S2877, 2017.

[61] M. Shokoohi, H. Shoorei, M. Soltani, S. H. Abtahi-Eivari, R. Salimnejad, and M. Moghimian, "Protective effects of the hydroalcoholic extract of Fumaria parviflora on testicular injury induced by torsion/detorsion in adult rats," Andrologia, vol. 50, no. 7, article e13047, 2018.

[62] J. Meštrović, Z. Pogorelić, I. Drmić-Hofman, K. Vilović, D. Todorić, and M. Popović, "Protective effect of urapidil on testicular torsion-detorsion injury in rats," Surgery Today, vol. 47, no. 3, pp. 393-398, 2017.

[63] R. H. Razooqi, M. J. Jalil, and M. K. AL-Fadhli, "Dietary parsley oil mitigates the negative alterations in testicular histomorphometric and semen quality in Japanese quail males during summer," Plant Archives, vol. 19, no. 2, pp. 3707-3714, 2019.

[64] M. N. Al-Shaikh, T. A. Abdul Wahab, and S. H. Abdul Kareem, "Hypothyroidism induced by carbimazole in diabetic mice and its management using parsley and Eruca sativa oil," IOSR Journal of Pharmacy and Biological Sciences, vol. 9, no. 1, pp. 24-27, 2014.

[65] M. R. Salahshoor, A. Abdolmaleki, C. Jalili, S. Roshankhah, and A. Ziapour, "Determination of histopathological and biomedical parameters in protective effects of Petroselinum crispum on hepatotoxicity induced by dichlorvos in male Wistar rats," Comparative Clinical Pathology, vol. 29, no. 2, pp. 501509, 2020.

[66] S. La Vignera and R. Vita, "Thyroid dysfunction and semen quality," International journal of immunopathology and pharmacology, vol. 32, 2018.

[67] V. Aiceles and C. da Fonte Ramos, "A link between hypothyroidism, obesity and male reproduction," Hormone Molecular Biology and Clinical Investigation, vol. 25, no. 1, pp. 5-13, 2016.

[68] G. M. Badr, H. Elsawy, A. Sedky et al., "Protective effects of quercetin supplementation against short-term toxicity of cadmium-induced hematological impairment, hypothyroidism, and testicular disturbances in albino rats," Environmental Science and Pollution Research, vol. 26, no. 8, pp. 8202-8211, 2019.

[69] A. A. Ibrahim, N. A. Mohammed, K. A. Eid, M. M. Abomughaid, A. M. Abdelazim, and A. M. Aboregela, "Hypothyroidism: morphological and metabolic changes in the testis of adult albino rat and the amelioration by alpha-lipoic acid," Folia Morphologica, vol. 80, no. 2, pp. 352-362, 2021. 